\title{
Dinosaurs and other vertebrates from the Papo-Seco Formation (Lower Cretaceous) of southern Portugal
}

\author{
S. Figueiredo ${ }^{1,2,3 *}$, P. Rosina ${ }^{1,3}$, L. Figuti ${ }^{4}$ \\ ${ }^{1}$ Unidade Departamental de Arqueologia, Conservação e Restauro e Património do Instituto Politécnico de Tomar, Quinta do Contador - \\ Estrada da Serra, 2300-313 Tomar, Portugal. \\ ${ }^{2}$ Centro Português de Geo-História e Pré-História - Prct. Campo das Amoreiras, Lt: $1-2^{\circ} \mathrm{O}$ - 1750-021 Lisboa, Portugal. \\ ${ }^{3}$ Centro de Geociências da Universidade de Coimbra, Rua Sílvio Lima, Univ. Coimbra - Pólo II, 3030-790 Coimbra, Portugal \\ ${ }^{4}$ Museu de Arqueologia e Etnologia da Universidade de São Paulo, Avenida Prof. Almeida Prado, 1466 - São Paulo SP, 05589000, Brazil
}

e-mail addresses: silverio.figueiredo@ipt.pt (SF; *Corresponding author); prosina@ipt.pt(PR); silverio.figueiredo@cpgp.pt(SF); lfiguti@usp.br(LF)

Received: 20 January 2015 / Accepted: 1 December 2015 / Available online: 20 December 2015

\begin{abstract}
New vertebrate remains reported from the Papo-Seco Formation (Lower Barremian, Lower Cretaceous) of Areias do Mastro, in Cabo Espichel, SW Portugal, south of Lisbon. The marine, lagoonal, and estuarine limestones, marls, sands and gravels have yielded remains of dinosaurs and other reptiles since the 19th century. Recent paleontological prospecting produced several vertebrate remains, including turtle shell fragments, crocodilian teeth, fish and pterosaurs. Research identified both bones and teeth of fish, crocodiles, dinosaurs Baryonyx and iguanodontian, as well as a ctenochasmatoid pterosaur, and a possible ornithocheirid pterosaur. These new disclosures are an important contribution to the knowledge of vertebrate diversity from the Portuguese Cretaceous. Faunal species combination proven to be similar to other faunal associations of Barremian formations in the Iberian Peninsula.
\end{abstract}

Keywords: Early Cretaceous, vertebrates, dinosaurs, pterosaurs, Espichel, Portugal

\begin{abstract}
Resumen
Se presentan nuevos restos fósiles de vertebrados de la formación Papo-Seco (Barremiense inferior, Cretácico Inferior), en el yacimiento de Areias do Mastro, SW de Portugal, al sur de Lisboa. En las margas, arenas, areniscas y calizas de origen marino y estuarino de esta formación localizada en el Cabo Espichel, y ya desde el siglo XIX, se han encontrado restos de dinosaurios y otros reptiles. Recientemente, nuestra prospección sacó a la luz varios restos fósiles de vertebrados, entre los que se incluyen fragmentos de caparazón de tortuga, dientes de cocodrilo, de peces actinopterigios y de pterosaurio (ctenocasmatoideo y posiblemente ornitoqueiroideo), así como algunos huesos y dientes de dinosaurios. Hemos identificado restos de Baryonyx y de ornitópodos iguanodontios. Su descubrimiento representa una importante contribución al conocimiento de la diversidad de vertebrados existentes en el Cretácico portugués. La combinación de las especies muestra ser similar a otras asociaciones de la fauna de las formaciones Barremienses en la Península Ibérica.
\end{abstract}

Palabras clave: Cretácico Inferior, vertebrados, dinosaurios, pterosaurios, Espichel, Portugal

\section{Introduction}

The Early Cretaceous was a key time in the evolution of terrestrial biota, marking the changeover from floras dominated by cycads and other gymnosperms to those dominated by angiosperms (Barrett and Willis, 2001; Lloyd et al., 2008). The rise of angiosperms was associated with the diversification of various insect groups, including butterflies, ants, bees, and wasps, as well as of insect-eating animals such as lizards, birds, and mammals. This modernisation of terrestrial biota seems to have occurred without much dinosaur involvement, which continued as the major large-sized terrestrial animals (Barrett and Willis, 2011; Lloyd et al., 2008), but the time in retrospect was crucial in marking the initiation shift from marine dominance to terrestrial biodiversity (Vermeij and Grosberg, 2011).

The Early Cretaceous vertebrates of the Iberian Peninsula are of scientific knowledge for some time, especially 
in eastern Spain sites such as Galve (Terue 1), Uña and Las Hoyas (Cuenca), Golmayo (Soria), for example (e.g. Estes and Sanchíz, 1982; Sanz et al., 1984; Buscalioni and Sanz, 1987; Ruiz-Omeñaca et al., 2004; Fuentes Vidarte et al., 2005; Ortega et al., 2006; Torcida Fernández-Baldor, 2006; Sánchez-Hernández et al., 2007; Buscalioni and Fregenal, 2010; Canudo et al., 2010; Pereda Suberbiola et al., 2012a), showing close similarity to the well-documented faunas from the Wealden of England, France, and Germany (e.g. Benton and Spencer, 1995; Batten, 2011). Reports of such faunas from the Cretaceous in Portugal have been more sporadic.

Portuguese Cretaceous vertebrates were first reported in the $19^{\text {th }}$ century, from the Cabo Espichel area, south of Lisbon, however the remains were rare and fragmentary. The Portuguese geological survey (Sauvage 1897, 1898) reported dinosaur and crocodile teeth from the Papo-Seco Formation, at Boca do Chapim's quarry. Later, Lapparent and Zbyszewski (1957) reported turtle remains and crocodile teeth and bones, as well as dinosaurian remains. Among the latter are two teeth fragments referred to megalosauridae (Lapparent and Zbyszewski, 1957), later classified as carnosauria incertae sedis (Galton, 1994). Some herbivorous dinosaur remains were also reported: teeth, caudal vertebrae and the distal end of a right femur identified as Iguanodon and teeth of Astrodon (=Pleurocoelus) valdensis (Lapparent and Zbyszewski, 1957; Dantas, 1990; Galton, 1994). According to Antunes and Mateus (2003) this sauropod teeth are insufficient to assign a specific classification. A tooth from Boca do Chapim (MGIGM.10), displayed in Museu Geológico's inventory to an Iguanodon, was, in 2000, identified as a cf. Pelorosaurus tooth (Figueiredo, 2000). These sauropod designations, whether Pelorosaurus or Astrodon, are in line with descriptions of material from various locations in the European Early Cretaceous, such as the English Wealden, despite affinities between these taxa being uncertain (Taylor, 2010).

Recently, a preliminary analysis of a new discovery of several bones of an ornithopod dinosaur in Boca do Chapim's quarry was reported (Figueiredo, 2010, 2014). Fragments of jaws found at Boca do Chapim by Sauvage (1897-1898) were identified as being from a crocodile (Suchosaurus girardi); they were later analysed by Buffetaut and classified as spinosaurid Baryonyx, based on similarities with the holotype of Baryonyx walkeri from the English Barremian (Buffetaut, 2007). Recently, Mateus et al. (2011) reported skull and postcranial bones also attributed to Baryonyx walkeri in a place they named Praia das Aguncheiras (Mateus et al., 2011), being the real topology Praia do Guincho.

Since 1999, Centro Português de Geo-História e PréHistória carried out research in the Papo-Seco Formation, during which a set of vertebrate remains (bones and teeth) were found: turtles, fishes, tetanuran theropods (including derived maniraptorans/birds) and iguanodontian ornithopods among dinosaurs (Figueiredo, 2002, 2004, 2005, 2007, 2008, 2014). The purpose of this paper is to publish the findings of
Areias do Mastro location. Although several vertebrate remains of the Papo-Seco Formation are known, this the first report of remains found at Areias do Mastro's quarry. The remaining quarries of Papo-Seco Formation enclosed the remains of vertebrates published from Boca do Chapim (Lapparent and Zbyszewski, 1957) and Praia das Aguncheiras (= Praia do Guincho) (Mateus et al., 2011).

Institutional abbreviations: CPGP, Centro Português de GeoHistória e Pré-História, Lisbon, Portugal; LAP - Laboratório de Arqueozoologia e Paleontologia do CPGP, Golegã, Portugal; MGLNEG, Museu Geológico do Laboratório Nacional de Energia e Geologia, Lisbon, Portugal.

\section{Geology}

Areias do Mastro is situated about $40 \mathrm{~km}$ south of Lisbon, in the SW of the Setúbal Peninsula, near Sesimbra (Fig. 1). It is a small beach at the bottom of the coastal cliffs of the Cabo Espichel anticline.

The Papo-Seco Formation was previously referred to as 'Grès marneux à grands sauriens' (Choffat, 1904-1907, p. 13), 'Grès aux dinosauriens' (Rey, 1972, p. 174), and 'Camadas com Iguanodon mantelli' (Ferreira, 1961, p. 255), the source of previously reported bones and teeth, as noted. It is dated as Lower Barremian (Rey, 1972; Manupella et al., 1999), 127 to 129.4 million years old, according to the International Chronostratigraphic Chart, 2015. This formation is about $18.5 \mathrm{~m}$ thick, characterized by its marls and greenish silty clays with lignite and gypsum. It presents intercalations of sandstones with horizontal stratification (Manupella et al., 1999). The fauna of this formation comprises remains of dinosaurs and invertebrates (bivalves and gastropods) in the coarse sandstone layers, and ostracods in the marls. At the upper boundary of this formation can be observed bioturbated silty limestone layers with oyster remains. The overall sedimentary setting is a mix of lagoonal and estuarine sediments (Manupella et al., 1999; Dinis et al., 2008).

The Papo-Seco Formation lies between Areias do Mastro and Boca do Chapim formations. The older layers, by the seashore, still belong to the Areias do Mastro Formation, showing marine carbonate limestone facies. On top of these layers sandstones can be clearly observed, indicator of an estuarine environment, which correspond to the beginning of the PapoSeco Formation (Fig. 2). Above these lay marly beds, which contain marine and terrestrial vertebrate remains.

The lowest layers of the Papo-Seco Formation, from Boca do Chapim at the southernmost entrance to Areias do Mastro, two faults of about $2 \mathrm{~m}$ thick of light-coloured marine limestone (Fig. 2), in terms of fauna, yield some fragments of turtle and gastropods shells, as well as some fish teeth. These initial layers are topped by a further two layers of thin yellowish sandstones.

Sedimentological analysis of the intermeddled layers (Table 1) demonstrates evolution from a lagoon-like (cat's-eye 

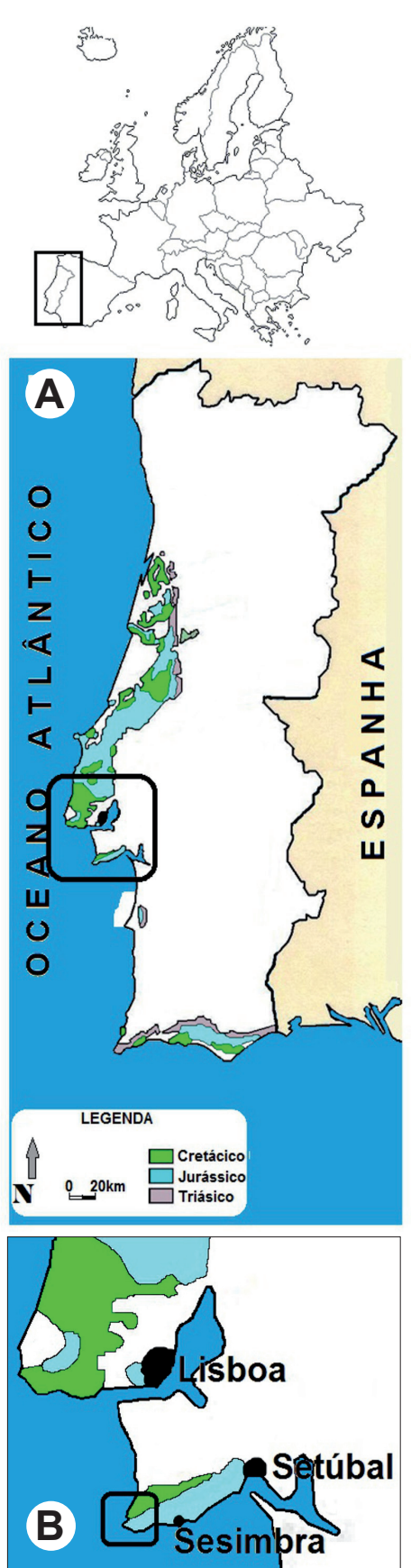
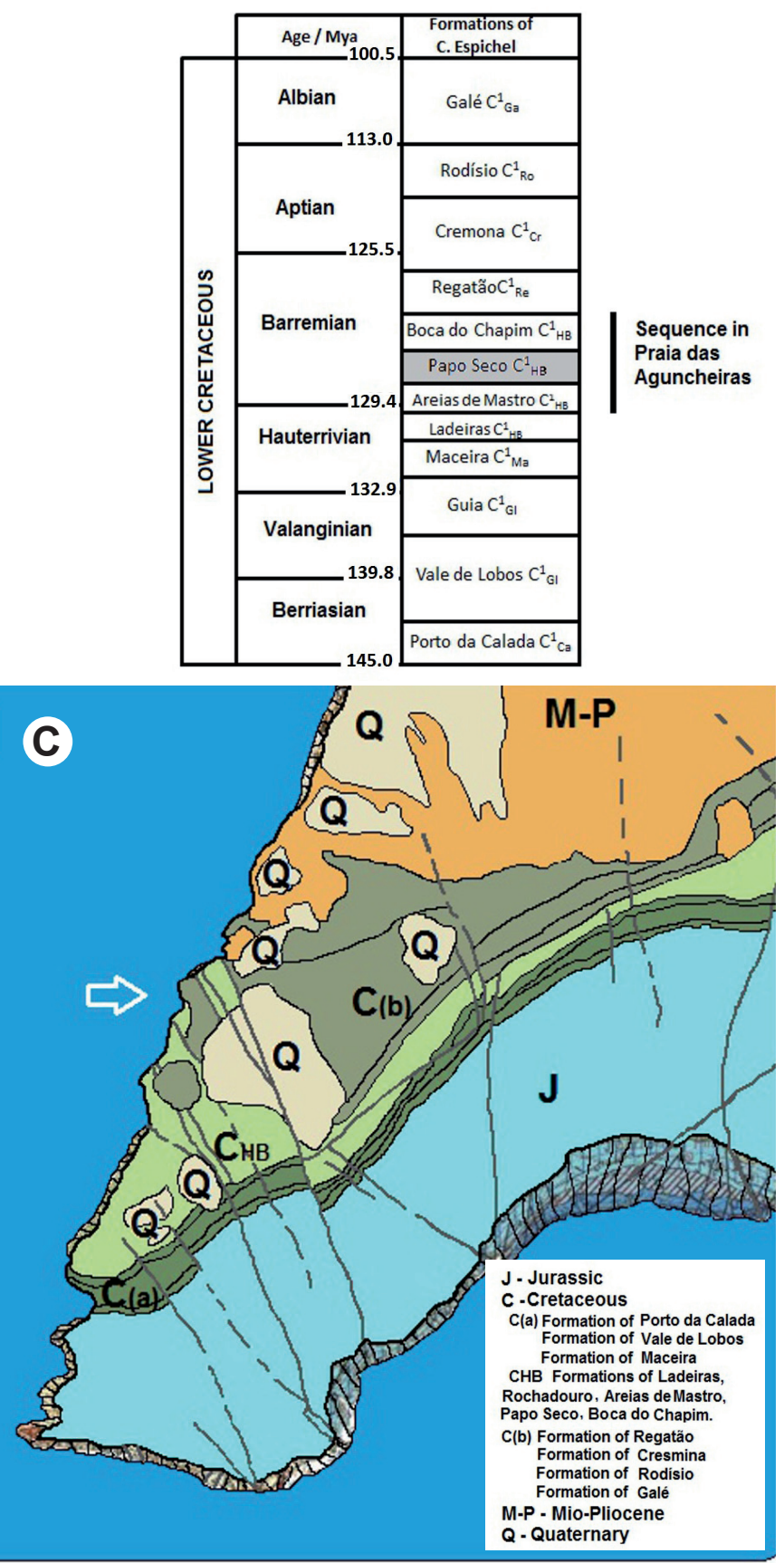

Fig. 1.- The locality Areias do Mastro and geological context, showing the Mesozoic of Portugal (A), the Mesozoic of the Lisbon and Setúbal Peninsulas (B), and the geology and geological formations of the Cabo Espichel and Areias do Mastro sequences (C). In (C) other locations where vertebrate remains from Papo-Seco Formation were identified are also marked. The dating of the Cretaceous ages are according to the International Chronostratigraphic Chart (2015).

pond) environment, more closed, witnessed by the prevailing fine fraction, to a coastal marine environment, as shown by the marly clays of the carbonate layers. Between these two phases, the increase in the sandy fraction indicates the opening of the lagoon and, possibly, an estuarine episode (with over $65 \%$ of sand). While carbonates increase progressively with increasing influence of marine processes, the concentration of organic matter could be related either to interplay of aerobic/anaerobic conditions during deposition, or to postdepositional processes.

\section{Materials and Methods}

The study is based on a collection of 22 vertebrate fossils from Areias do Mastro, curated in the palaeontology collection of CPGP. These materials result from prospecting at the cliffs of Areias do Mastro (1998-2003) and the excavation of four clay layers in the lower part of the cliffs (2004-2009). The paleontological research coordinated by SF as part of a wider project that includes the pre-historic archaeology of the whole Cabo Espichel area. 


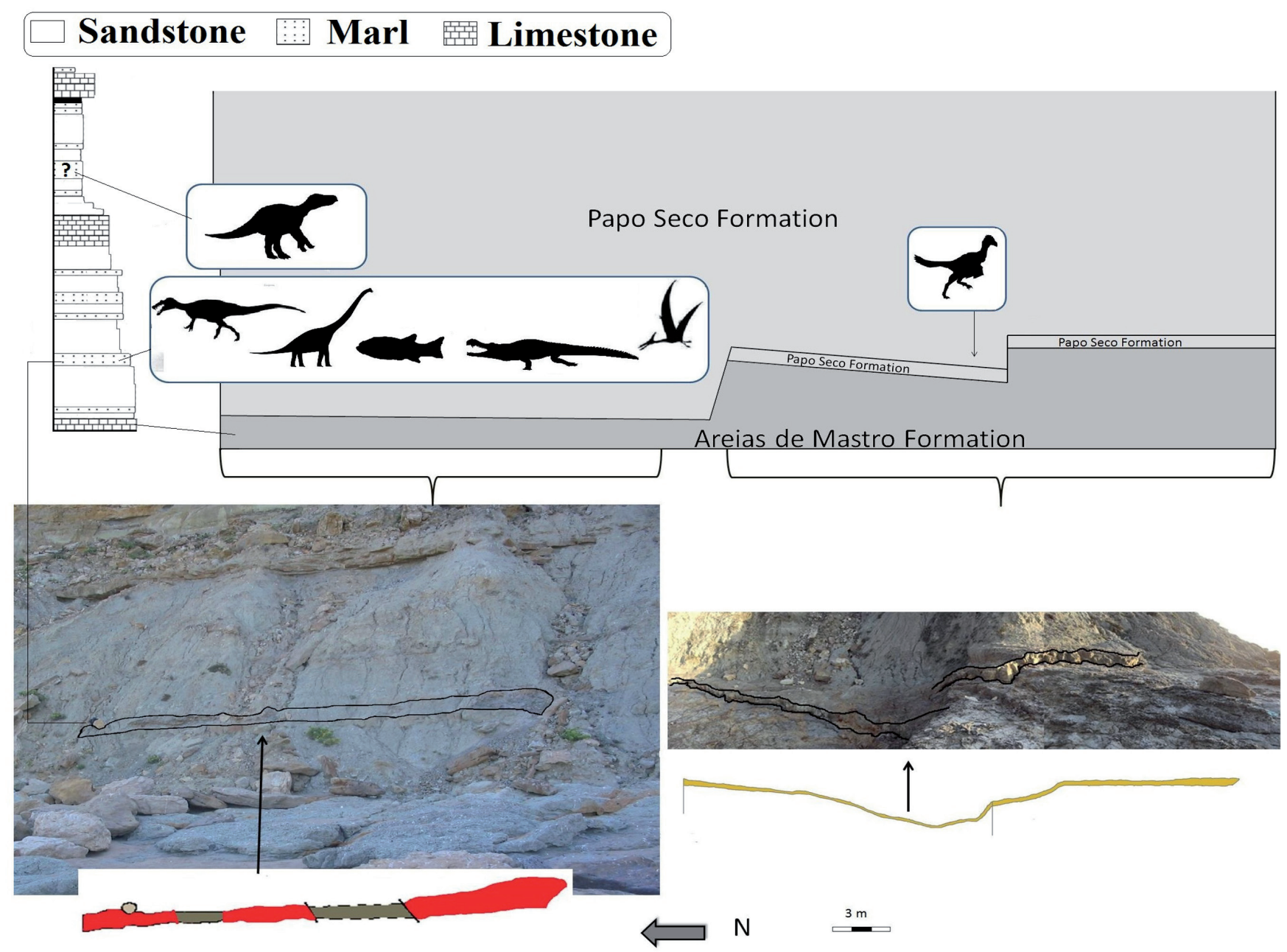

Fig. 2.- The Areias do Mastro locality, summary sedimentary log, showing vertebrate-bearing units (top left), diagram of cliff section, showing the two faults, and the Papo-Seco and Areias do Mastro formations (top right), and (bottom) photographs of the surveyed sites, showing fossiliferous beds highlighted.

\begin{tabular}{cccccc}
\hline & Description & Sand fraction & Organics & Carbonates & Interpretation \\
\hline C1 & Clay & $10 \%$ & $1.1 \%$ & Residual & Lagoon/Coastal lake \\
C2 & Sandy clay & $27.6 \%$ & $0.6 \%$ & $3.9 \%$ & Transition to open environment? \\
C3 & Sandy loam (slightly marly) & $65.02 \%$ & $2.9 \%$ & $8.55 \%$ & Estuarine \\
C4 & Marly sandy clay & $35.69 \%$ & $0.4 \%$ & $20.64 \%$ & Marginal marine carbonate facies \\
\hline
\end{tabular}

Table 1.- Basic sedimentological characterisation of the lowest layers of the Papo-Seco Formation, in Areias do Mastro (Cabo Espichel, Portugal).

In the laboratory (LAP), the materials were cleaned and measured followed by a taxonomic study, through a comparison, analysis of the main characteristics of the studied fossils, and biometric studies. The measurements used for tooth analysis CPGP.1.06.2 followed Smith et al.'s (2005) methodology. For the measurement of fish teeth, only three dimensions were considered: length, width and crown height. In Hospital de Seia and in laboratory of Setpet was made a radiographically study of CPGP.01.99.1.

\section{Systematic palaeontology}

\subsection{Actinopterygians}

OSTEICHTHYES Huxley 1880

ACTINOPTERIGII Cope 1871

SEMIONOTIFORMES Arambourg \& Bertin 1958

Genus: LEPIDOTES Agassiz 1832

CF. LEPIDOTES SP. 

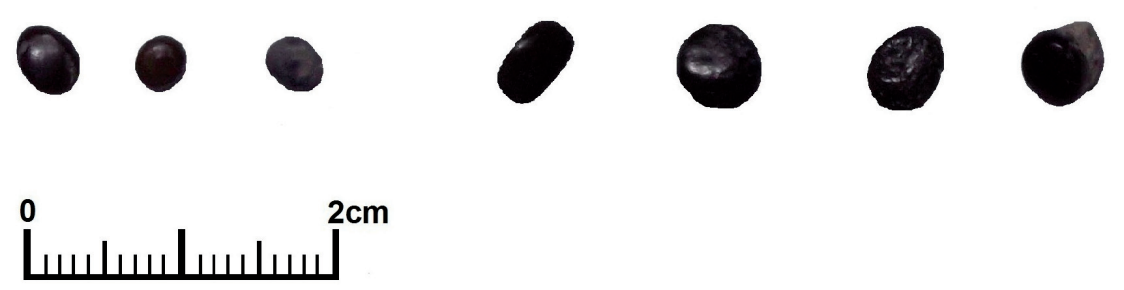

Fig. 3.- Teeth of $c f$. Lepidotes sp from the Papo-Seco Formation of Areias do Mastro.
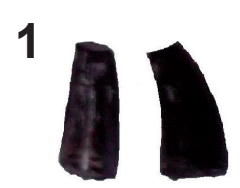

a $\quad$ b $\quad$ c

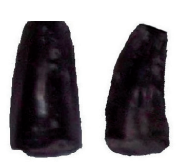

c d
2

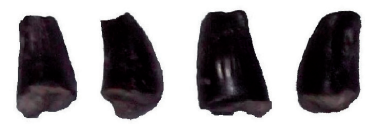

a $\quad$ b $\quad c \quad d$
3

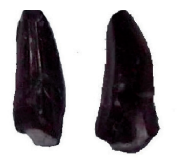

a b
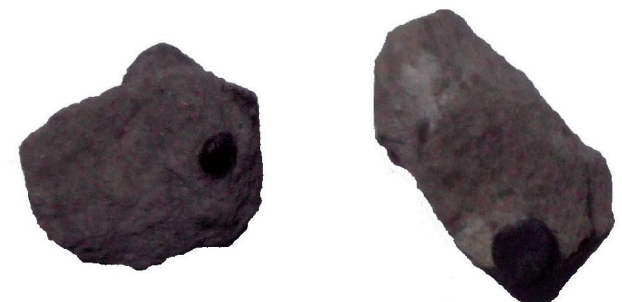

Fig. 4.- Teeth of cf. Anteophthalmosuchus, sp : 1 - CPGP.1.03.1; 2 - CPGP.1.03.7; 3 - CPGP.1.05.9; 4 - CPGP.1.06.71 (a) labial surface; b) distal surface; c) lingual surface; d) medial surface).

Material: CPGP.1.05.3; 4; 5; 6; 7; 8 and $24 ;$ and CPGP.1.07.5; and 21. 9 teeth.

Description: 11 hemi-ellipsoid or round and flattened teeth (Fig. 3: 1-9), from 3-6 mm in diameter, and with smooth occlusal surfaces and flat bases on the insertion side. The sedimentary analyses and the few fish remains identifiable indicate the presence of the shallow seas inhabitant Lepidotes, which present very characteristic of this genus: The material of Areias do Mastro shows that the marginal teeth are compressed and the inner teeth are smooth and less elongated than the teeth of Pycnodus.

\subsection{Crocodyliforms}

CROCODYLIFORMES Hay 1930

NEOSUCHIA Benton and Clark 1988

GONIOPHOLIDIDAE Cope 1875

ANTEOPHTHALMOSUCHUS Salisbury and Naish, 2011 Cf. ANTEOPHTHALMOSUCHUS SP.

Material: CPGP.1.03.1 (Fig. 3, 10 to 13); PGP.1.03.7 (Fig. 3: 14-17); CPGP.1.05.9 (Fig. 3: 18-21); CPGP.1.06.71 (Fig. 3: 22-25); CPGP.1.06.81 (Fig. 3: 26-29). 5 teeth.

Description: Five caniniforms teeth, conical and curved towards the lingual side, with sharp crowns, and with very fine longitudinal striations, further marked on the lingual side when compared with the labial surface. The carinae are not serrated or jagged. The base is circular, but the crown is subcircular in cross section.

These teeth exhibit characteristics of the goniopholidid group described by Andrade et al: The crown is subcircular in cross section, without evident lateral compression, but the lingual and labial surfaces are asymmetric. The labial face is strongly arched, whereas the lingual is not as much. Enamel ornamentation is present on both lingual and labial surfaces, in the form of basi-apical ridges. These are well defined, conspicuous, and closely packed, however low. Overall, the ornamentation is non-anastomosed. A distinct keel runs on mesial and distal faces of the crown (Andrade et al., 2011, p. 82). We found also the characteristics described by PuértoasPascual et al. (2015) to the $G$ anteophthalmosuchus specimen of Teruel (Spain): they are conical, relatively short and robust, with the labial surface more convex than the lingual surface. The posterior surface is slightly shorter and slender. Two carinae are well developed in the anterior and posterior surfaces of the teeth; these carinae are basoapically straight (Puértoas-Pascual et al., 2015, p. 46).In CPGP.1.03.1 and PGP.1.03.7, the apex is broken, CPGP.1.05.9 has its apex worn, and the base and the labial face broken in the mesial area, CPGP.1.06.71 consists only of the apex, while CPGP.1.06.81 has the apex broken and the face worn.

\subsection{Pterosaurs}

\section{PTERODACTYLOIDEA Plieninger 1901 \\ ORNITHOCHEIROIDEA Seeley, 1870 \\ ORNITHOCHEIRIDAE Seeley 1870 \\ ORNITHOCHEIRIDAE indet.}

Material: CPGP.1.03.2 (Fig. 3: 30-33). One tooth.

Description: Sharp tooth, concave on the distal and curved in the mesial edge, slightly bent in the apical, to the lingual side. It presents some of the characteristics of plesiosaur teeth: the cross-section is compressed enough buccolingually, with smooth carinae, not serrated and pronounced in the medial and apical portions; the enamel has fine grooves which branch off towards the base. Slender recurved teeth are present in ornithocheirid pterosaurs and elasmosaurid plesiosaurs, but in ornithocheirids the enamel surface is generally smooth, restricted to the apex of the tooth, and asymmetrically distributed (Averianov, 2007; Sweetman and Martill, 2010). 
CTENOCHASMATOIDEA Unwin, 2003

CTENOCHASMATOIDEA indet.

Material: There are two specimens identified as ctenochasmatoid pterosaur teeth, one relatively complete (CPGP.1.09.1) and one much less so (CPGP.1.04.3).

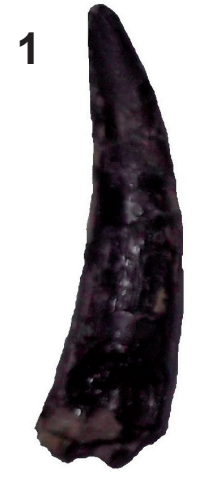

a

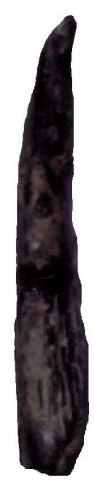

b

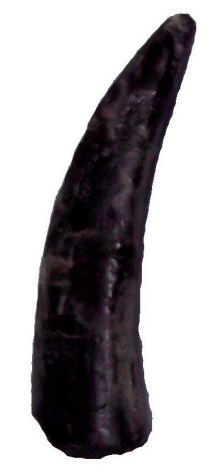

C

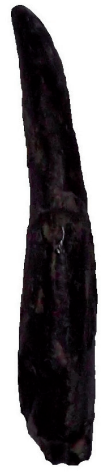

d

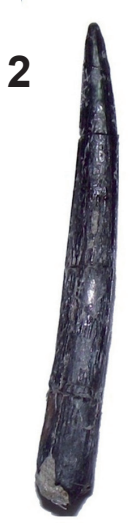

a

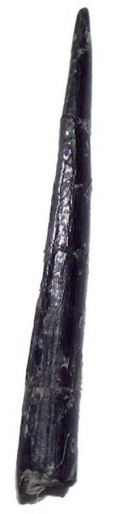

b

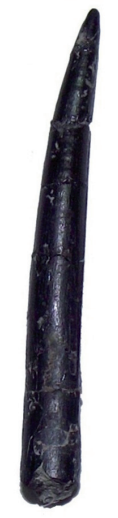

C

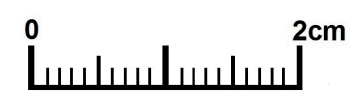

Fig. 5.- Tooth of Ornithocheiridae indet. (CPGP.1.03.2: a) labial surface; b) distal surface; c) lingual surface; d) medial surface); Tooth of Ctenochasmatoidea indet. (CPGP.1.09.1 : a) labial surface; b) distal surface; c) medial surface).
Descriptions: The more complete tooth (CPGP.1.09.1; Fig. 3: 34-36) is needle-like, $35.8 \mathrm{~mm}$ long, and measuring 4.6 $\mathrm{mm} \times 4.3 \mathrm{~mm}$ at the base. The specimen is a single tooth crown, covered from bottom to top in enamel. At the base, the tooth wall is thin and the interior is filled with sediment, suggesting a deep pulp cavity, but the extent of this pulp cavity cannot be determined. The degree of curvature is modest, amounting to an offset of only $2.3 \mathrm{~mm}$ from the tip to a horizontal line projected from the base of the preserved tooth. The tooth is more or less circular in cross section from tip to base, but the cross section becomes slightly extended distally, marked by a posterior carina that runs for $80 \%$ of the length of the tooth from below the tip to the base. The surface of the enamel is generally smooth, and only lightly pitted, but with some slight longitudinal ridges, each 0,05 mm wide, and running for much of the length of the tooth, on the labial face.

The less complete specimen (CPGP.1.04.3) is $11.7 \mathrm{~mm}$ long and measures $4.2 \mathrm{~mm} \times 3.2 \mathrm{~mm}$ at one end. According to its general appearance and following cues from measurements, it is likely a broken middle section from a needle-like tooth, as described. It shows the same dimensions, cross-sectional shape, and surface texture as the complete tooth crown.

\subsection{Dinosaurs}

\subsubsection{Saurischians}

THEROPODA Marsh 1881

SPINOSAURIDAE Stromer 1915

BARYONYX Charig and Milner 1986

$B A R Y O N Y X \mathrm{sp}$.

Comments: As already mentioned, in the 19th century, in the Papo-Seco Formation, in deposits from the Boca do Chapim, fragments of a maxilla and a jaw were found by the French palaeontologist H. E. Sauvage, who attributed them

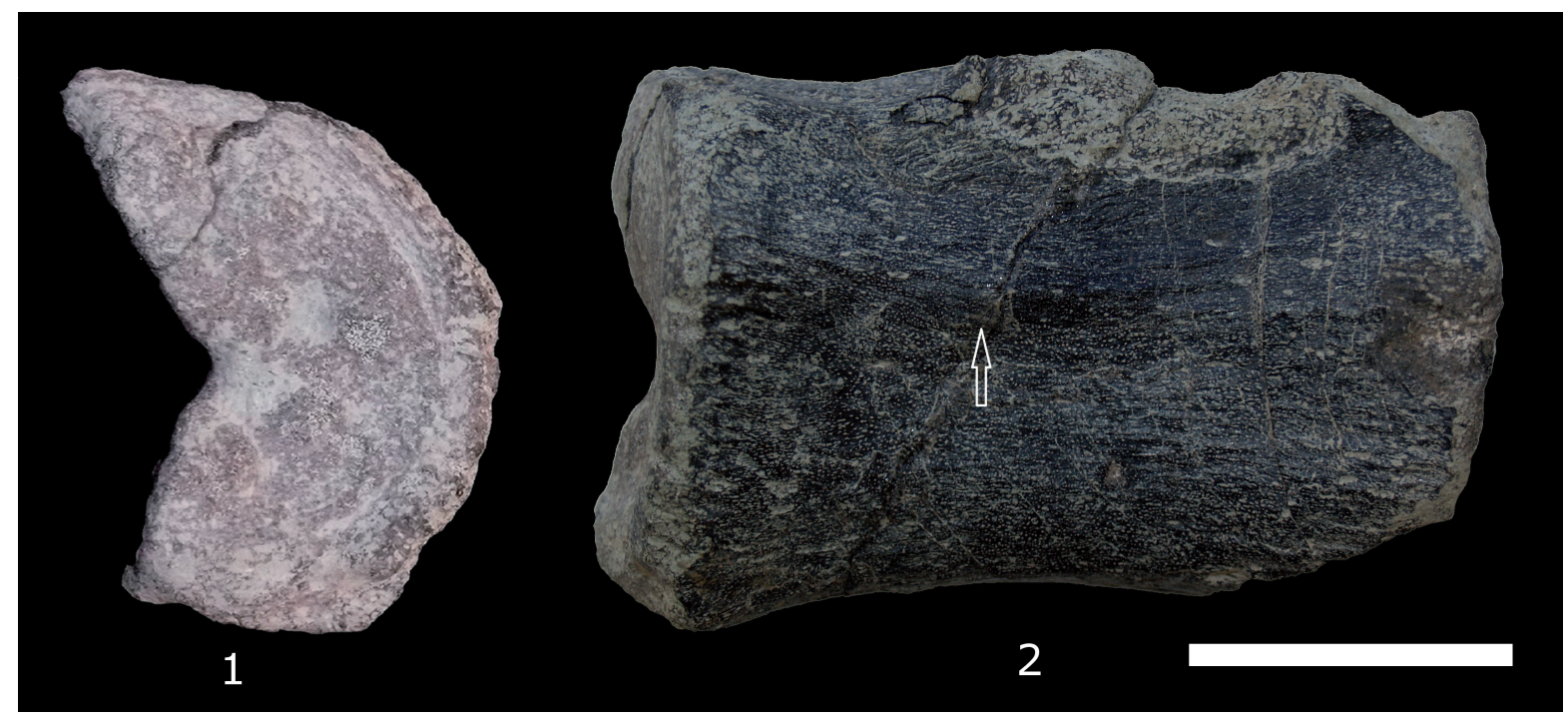

Fig. 6.- Vertebra of sauropod. (1 - proximal view; 2 - left lateral view). The arrow shows the prominence with a horizontal ridge. Scale: $5 \mathrm{~cm}$. 
to a crocodile, Suchosaurus girardi, (Sauvage, 1898). However, these remains were revised in 2007 by H. Buffetaut, who attributed them to Baryonyx based on similarities with the holotype of Baryonyx walkeri from the English Barremian (Buffetaut, 2007). More recently, O. Mateus and collaborators reported the discovery of a set of bones (from the cranial and post-cranial skeleton) from about $1 \mathrm{~km}$ to the north of Areias de Mastro, in Praia do Guincho, and assigned the material to Baryonyx walkeri (Mateus et al., 2011).

Material: CPGP.1.06.2 (Fig. 3: 37-40). One tooth.

Description: Ziphodont conical tooth, curved, with the crown narrow and pointed, with longitudinal grooves in the apical and medial areas. The base has no ornamentation. It has a worn apex. The distal carina is sharp and micro-serrated (Fig. 5.2). The mesial carina has a long and wide longitudinal groove, which seems to result from normal wear of the tooth. This tooth is identified as Baryonyx sp., based on its overall shape and surface ornaments, further confirmed by the biometric study: our measurements of CPGP.1.06.2 are within the range of values obtained by Smith et al. (2005) for Baryonyx from the British Wealden (Table 2). Furthermore, this tooth shows the characteristics of the Baryonyx teeth described in several studies (Charing and Milner, 2007; Smith et al., 2005; Fowler, 2007; Buffetaut, 2007, 2012; Alonso and Canudo, 2015; Alonso et al., 2015). These characteristics are: subcircular cross section, moderate lingual curvature, carinae located on the mesiodistal axis of the crown, six ridges. The CPGP.1.06.2 does not have fluted enamel on the labial surface or any microgranular ornamentation on the edges, but it has very fine denticles, from the apex to the base, with very high density, with 7 denticles per mm (Fig. 5.2). These last three characteristics are present in the morphotype of baryonychine teeth but not in other spinosaurids (Alonso and Canudo, 2015).

SAUROPODOMORPHA Hune, 1932

SAUROPODAMarsh, 1878

SAUROPODA indet.

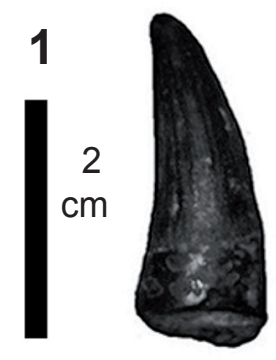

a

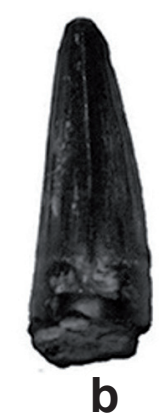

b
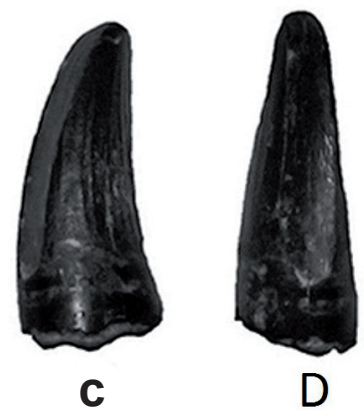

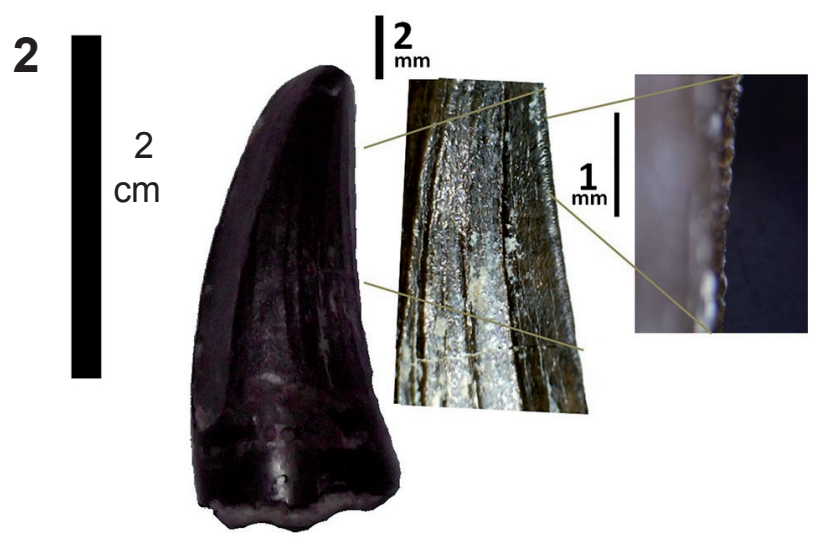

Fig. 7. - Tooth of Baryonyx sp., CPGP.1.06.2. In 1: a) labial surface; b) distal surface; c) lingual surface; d) medial surface. 2: Showing micro-serrations.

Material: CPGP.1.06.33 (Fig. 6). One caudal vertebra.

Description: the right side of the centrum of a distal caudal vertebra with the base of the neural arch. It has a subcylindrical shape (length, $11.4 \mathrm{~cm}$; proximal height, $7.5 \mathrm{~cm}$; distal height, $7.4 \mathrm{~cm}$ ) and it is laterally and ventrally concave. The posterior condyle is slightly displaced dorsally and the cotyle is concave. The central zone of the lateral surface has a large and lower prominence with a horizontal ridge. In Portugal the remains of Early Cretaceous sauropods are rare, however the most represented group of sauropods in the Cretaceous of the Iberian Peninsula are the Titanosauriformes (Ortega et al., 2006, p. 226, Mannion et al., 2013). On

\begin{tabular}{cccccccccc|cc}
\multicolumn{10}{c}{ Values BMNH } \\
\hline & $\begin{array}{c}\text { CPGP } \\
1.06 .2\end{array}$ & $\begin{array}{c}\text { BMNH } \\
\text { R9951 } \\
(\mathrm{pm4})\end{array}$ & $\begin{array}{c}\text { BMNH } \\
\text { R9951 } \\
(\mathrm{pm})\end{array}$ & $\begin{array}{c}\text { BMNH } \\
\text { R9951a }\end{array}$ & $\begin{array}{c}\text { BMNH } \\
\text { R9951D }\end{array}$ & $\begin{array}{c}\text { BMNH } \\
\text { R9951E }\end{array}$ & $\begin{array}{c}\text { BMNH } \\
\text { R9951F }\end{array}$ & $\begin{array}{c}\text { BMNH } \\
\text { R9951G }\end{array}$ & $\begin{array}{c}\text { BMNH } \\
\text { R9951H }\end{array}$ & $\begin{array}{c}\text { Lowest } \\
\text { Value }\end{array}$ & $\begin{array}{c}\text { Highest } \\
\text { value }\end{array}$ \\
\hline CBL & 12.20 & 13.06 & 10.49 & 11.69 & 15.76 & 13.18 & 12.12 & 16.42 & 16.47 & 10.49 & 16.47 \\
CBW & 10.80 & 11.24 & 7.90 & 11.19 & 12.05 & 10.88 & 10.35 & 15.19 & 13.65 & 7.90 & 15.19 \\
CH & 28.11 & 31.37 & 23.72 & 28.72 & 34.8 & 29.67 & 27.19 & 38.55 & 34.12 & 23.72 & 38.55 \\
AL & 27.39 & 32.29 & 24.77 & 29.22 & 37.41 & 30.52 & 30.46 & 43.88 & 38.11 & 24.77 & 43.88 \\
CA & $80.62^{\circ}$ & $82.96^{\circ}$ & $80.56^{\circ}$ & $82.42^{\circ}$ & $83.39^{\circ}$ & $82.60^{\circ}$ & $81.14^{\circ}$ & $83.60^{\circ}$ & $83.08^{\circ}$ & $80.96^{\circ}$ & $83.60^{\circ}$ \\
CBR & 0.885 & 0.860 & 0.753 & 0.957 & 0.764 & 0.825 & 0.853 & 0.922 & 0.829 & 0.753 & 0.957 \\
CHR & 2.304 & 2.401 & 2.261 & 2.456 & 2.208 & 2.251 & 2.243 & 2.347 & 2.071 & 2.071 & 2.456 \\
CBL/CBW-R & 1.130 & 1.162 & 1.328 & 1.045 & 1.308 & 1.211 & 1.171 & 1.081 & 1.206 & 1.045 & 1.328 \\
\hline
\end{tabular}

Table 2.- Key measurements of tooth CPGP.1.06.2 and known teeth of Baryonyx from the British Museum of Natural History (BMNH). Abbreviations: AL: apical length; CA: crown angle; CBL: crown base length; BR: crown base ratio; CBW: crown base width; CH: crown height; CHR: crown height ratio; $C B L / C B W-R$ : crown base length / crown base width ratio. 

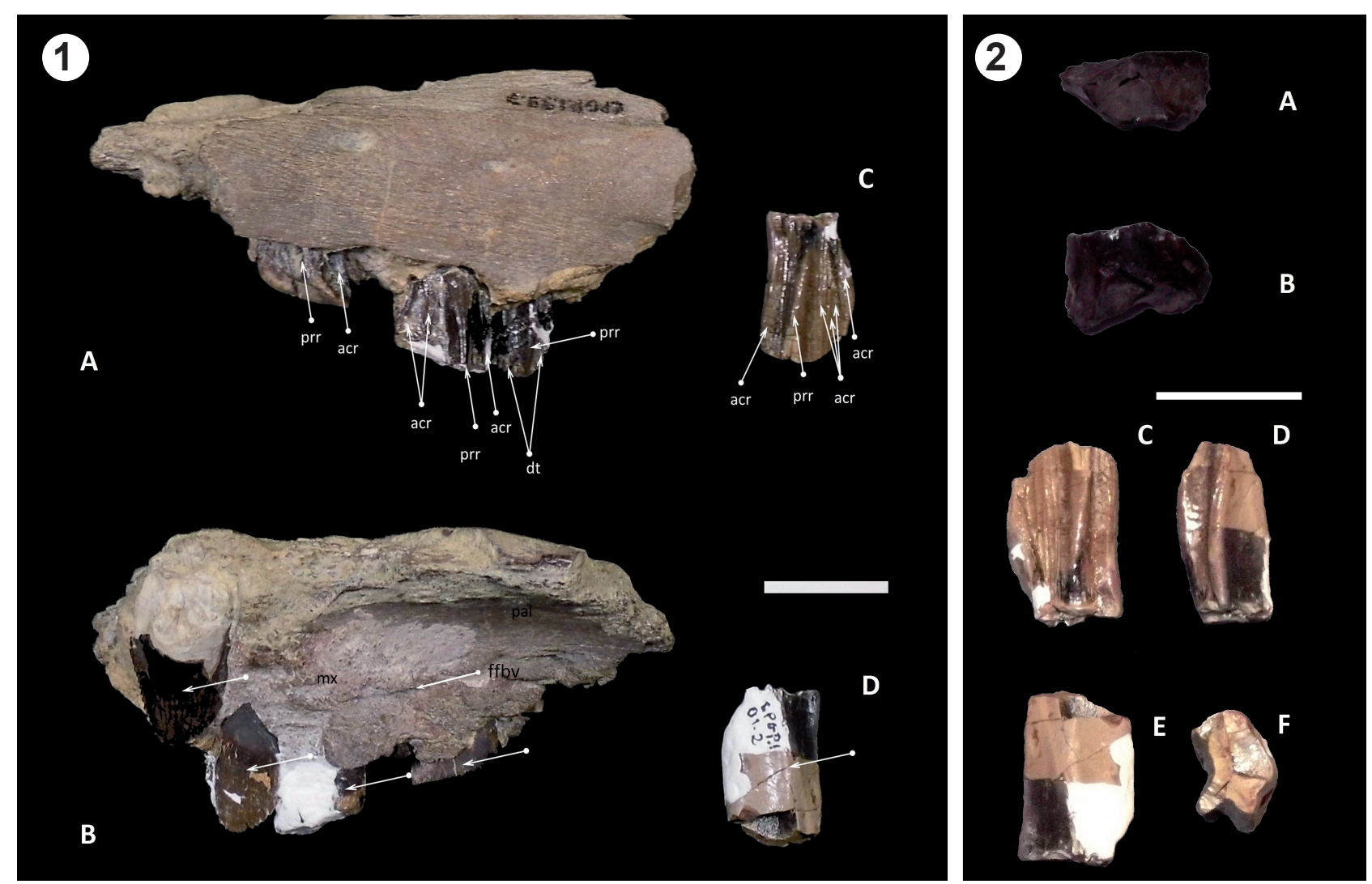

Fig. 8.- 1) Maxilla and Tooth of Iguanodontidae indet., CPGP.1.99.7. and CPGP.1.01.2. Above, labial view; below, lingual view. Abbreviations: mx - maxilla; acr - accessory crown ridges; prr - primary ridge; $\mathrm{dt}$ - denticulate margin of the teeth; ffbv: foramina for blood vessels. The arrows demonstrate that the teeth do not have any ornamentation on the lingual surface. Scale: 1cm; 2) (a and b) - Styracosterna indet., CPGP.1.03.3 a) lingual surface; b) top view; (c to f) 43-46, Iguanodontidae indet., CPGP.1.01.2 c) labial surface; d) distal surface; e) lingual surface; f) top view. Scale: $2 \mathrm{~cm}$.

the Papo-Seco Formation two teeth of Pleurocoelus (= Astrodon) valdensis, found in Boca do Chapim were described (Lapparent and Zbyszewski 1957, p. 46), as a brachiosaurid (basal titanosauriform).

\subsubsection{Ornithischians}

In the Papo-Seco Formation there are remains of the axial and appendicular skeleton and teeth attributed to Iguanodon mantelli (=Dollodon bampingi), by Lapparent and Zbyszewski (1957), previously this material was referred to Iguanodon sp. by Antunes and Mateus (2003), and to Iguanodon atherfieldensis (=Mantellisaurus atherfieldensis) by Crespo (2001, 2002), there are also several remains of the axial and appendicular skeleton of a large ornithopod (preliminary analysis in Figueiredo, 2010, 2014), both remains found in the quarry of Boca do Chapim. In Areias de Mastro three remains of the cranial skeleton (two teeth and a maxilla fragment) of ornithopods were discovered. In other Lower Cretaceous localities from Iberian Peninsula were described Iguanodonts remains, such as Mantellisaurus (=Iguanodon cf. mantelli) (Sanz et al. 1984; Llandres Serrano et al., 2013), Delapparentia (RuizOmeñaca, 2011; Gasca et al., 2014,) and Iguanodontia indet. (Pereda Suberbiola et al., 2011) from Barremian; Iguanodon (Gasulla et al., 2014), from Aptian; and Proa (McDonald et al., 2012), from Albian. Delapparentia and Proa are only described in Iberian Peninsula (Gasca et al., 2015).

\section{ORNITHOPODA Marsh, 1881 ORNITHOPODA INDET.}

\section{Material: CPGP.1.03.3 (Fig. 3: 41, 42). One tooth}

Description: Fragment of the lingual part of the crown of a left denture tooth. It is shows some wear on the occlusal surface. It has no kind of ornamentation. In the distal area, the surface is flat, making an angle with the lingual zone. The mesial area is curved.

\section{IGUANODONTIA Dollo, 1888 \\ ANKYLOPOLLEXIA Sereno, 1986 \\ STYRACOSTERNA Sereno, 1986 \\ IGUANODONTS}

The remains (a maxilla fragment and a tooth) show features of iguanodonts. However, in recent years the taxa related to Iguanodon have been revised. Despite revision, the current analysis frames the remains in the group of iguanodonts, also describing and grouping the characteristics of these findings within the recently revised genera identified in this group. The study of this material was done by comparison of the 


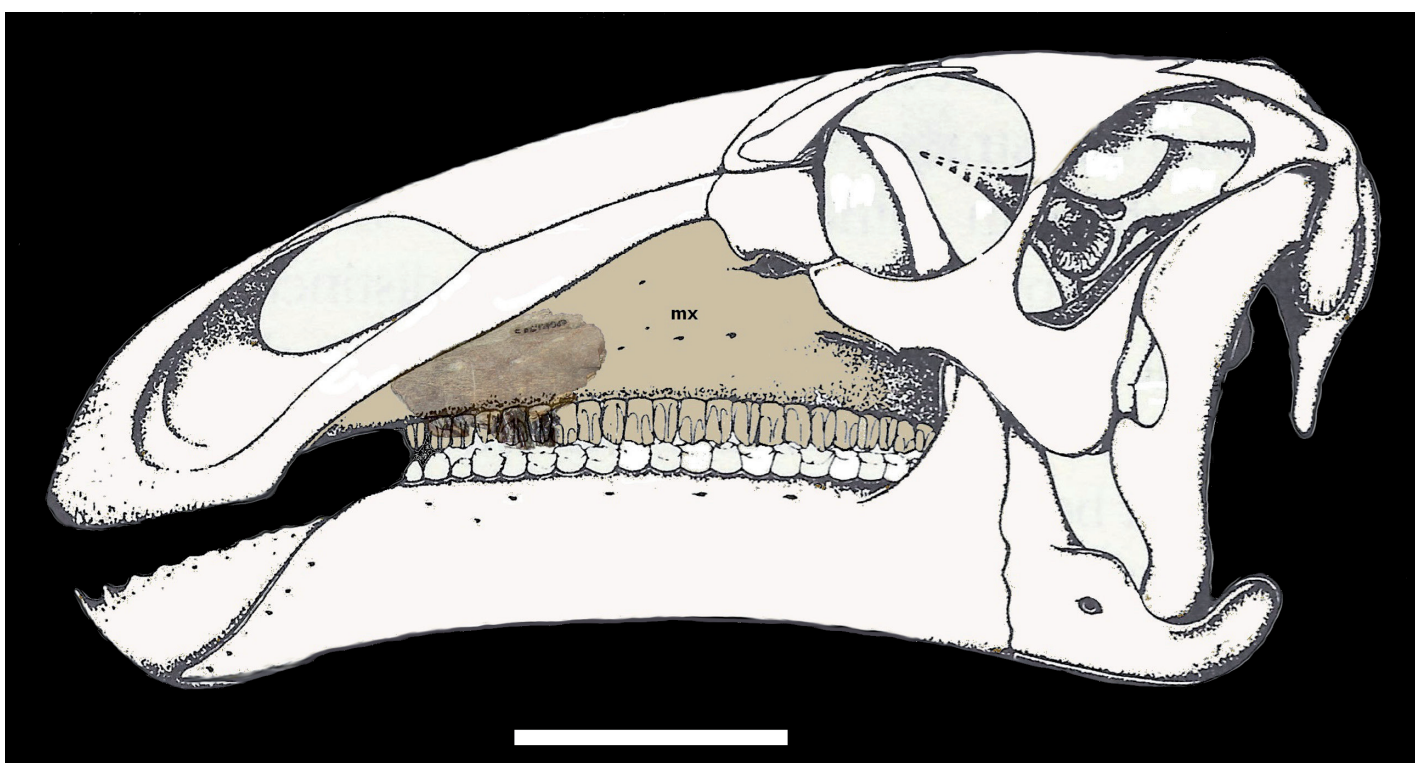

Fig. 9.- Maxilla of Iguanodontidae indet. (CPGP.1.99.7) in its place on the skull of a M. atherfieldensis. Drawing withdrawn from Norman (2013). Scale: $10 \mathrm{~cm}$

discretion of the teeth and maxilla of Iguanodonts described in the Barremian of Western Europe defined by Carpenter and Ishida (2010), Ruiz-Omeñaca (2011) and Norman (2013). The following species are signed: Dollodon seelyi (nomen dubium, Norman, 2013), Iguanodon bernissartensis, Mantellisaurus atherfieldensis Proplanicoxa galtoni and Delapparentia turolensis. Of these species the Iguanodon bernissartensis, Mantellisaurus atherfieldensis and Delapparentia $s p$ have cranial skeleton elements described (Norman and Weishampel, 2004; Paul, 2007, 2011; Norman, 2011a, 2013; Gasca et al., 2015).

Material: CPGP.1.99.7 (Figs. 8, 9 and 10); CPGP.1.01.2 (Fig. 3 and 6: 43-46). A maxilla fragment and a tooth.

Description: A fragment of the left part of a maxilla, with part of the palate and five teeth (two with the crown completely above the alveolar parapet, one with the apex above and two still within the alveoli). This fossil is $9.8 \mathrm{~cm}$ long and it has a robust appearance. It has three foramina, which circumscribes the alveolar parapet, it has two teeth with triangular crown, strongly denticulated and two other teeth with a semi-rectangular crown that have a very large primary ridge (Fig. 6). It has some features of the Iguanodontidae teeth noted by Norman and Weishampel (2004); Paul, (2007, 2011) and Norman, $(2011,2013)$, such as possessing only one replacement tooth per tooth position, the labial surface of the crown is thickly enameled and has a strongly denticulate margin and is dominated by a very large primary ridge arising from the base of the crown. On the labial surface there are grooves or lines and a less prominent second ridge. The teeth do not display any ornamentation on the lingual surface. In lateral view of maxilla there are tree foramina for alveolar nerve and, in medial view, we can identify two foramina for blood vessels.

From X-ray analysis (Fig. 10), it is possible distinguish the dental alveoli, which are wide and deep, revealing a long root. In this x-ray is clearly observed only one replacement tooth per tooth position.

The estimate length of CPGP. 01.99 .7 (approx. $30 \mathrm{~cm}$ ), considering the size of the teeth, places it between that of a Mantellisaurus atherfieldensis (=Iguanodon atherfieldensis) $(27 \mathrm{~cm})$ and that of a Iguanodon bernissartensis (39 $\mathrm{cm})$ (Norman and Weishampel, 2004). The foramens of insertion of the jaw muscles are less prominent than those of I. bernissartensis, and similar to those of M. atherfieldensis (Fig. 8). Considering the length and the characteristics of the foramens of jaw muscles insertion from the CPGP. 01.99.7, it appears closer to M. atherfieldensis than to I. bernissartensis. Furthermore, the CPGP.1.01.2 and the teeth of CPGP.1.99.7 have a different shape and ornamentation of those of Delapparentia sp (Gasca et al., 2014, fig. 2), in particular the shape and position of the ridges.

CPGP.1.01.2 is an isolated tooth. It displays the same dimensions (Table 3 ) and it holds, from the lingual view, the same characteristics of the cheek teeth of the CPGP.1.99.7. The difference is the presence of 8 accessory ridges, between the primary ridge and the marginal ridges $(5$ between primary ridge and the anterior marginal ridge and 3 between the primary ridge and the posterior marginal ridge). Identifying some features of the iguanodonts teeth noted by Galton $(1994$, p. 258) such as a free edge with small marginal denticles and a distinct ridge. From the posterior viewpoint, the marginal edge is curved. The lingual surface is slightly convex and without any ornamentation.

\section{Discussion}

\subsection{Identifications}

Most of the identifications, especially those of fish and crocodilian teeth are explained above, and follow standard 


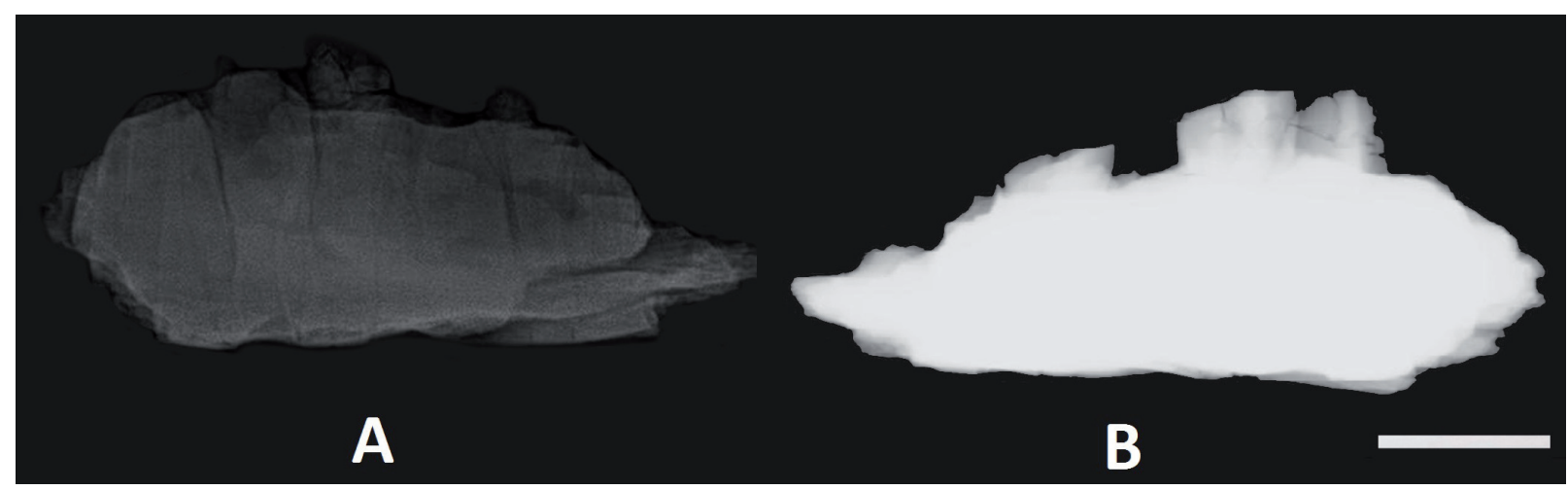

Fig. 10.- Radiography of the Maxilla of Iguanodontidae indet. (set in the radiography of Hospital de Seia by Natalina Pimenta and Bruno Ferreira (A) and laboratory of Setpet, by Sandra Subtil (B). A - labial view, B - palate view.

\begin{tabular}{c|cc}
\hline \multicolumn{1}{c}{ CPGP.1.01.2 } & CPGP.1.99.7 \\
\hline CBL & 15 & 15 \\
CMW & 15 & 15 \\
CH & 12 & 11 \\
Lapex & 8 & 8 \\
\hline
\end{tabular}

Table 3.- Measurements (in $\mathrm{mm}$ ) of the iguanodontian maxillary teeth. Abbreviations: Lapex: apex length; CBL: crown base length; $\mathrm{CBW}$ : crown base width; $\mathrm{CH}$ : crown height.

procedure, however the pterosaur and dinosaur fossils require more justification and discussion.

As for the teeth assigned to pterosaurs, such long needlelike teeth could be ascribed to a marine reptile such as an ichthyosaur or a plesiosaur, or even to a pterosaur or a crocodilian. In all these groups there are many taxa which jaws were lined with close-packed rows of slender teeth, where maxillary and mandibular tooth sets are interlocked as the jaws closed, a classic adaptation for catching fish (Massare, 1987). We exclude ichthyosaurs and plesiosaurs because no known specimens have such long and slender, needle-like teeth. Further, ichthyosaurs and plesiosaurs are generally rare in the Early Cretaceous, especially so in continental sediments. This leaves crocodilians and pterosaurs as possible candidates. The posterior carina and the full-length enamel covering could indicate that this tooth comes from a crocodilian rather than a pterosaur. In pterosaurs, the enamel ends well above the base of the crown: in a ctenochasmatid pterosaur from the English Middle Jurassic, the enamel extends over $80 \%$ of the length of the crown of the tooth, and $63 \%$ of the length of the whole tooth, including the crown (Buffetaut and Jeffrey, 2012). However, the present tooth shows the same modest curvature and slight ridging identified in ctenochasmatid pterosaur teeth (Buffetaut and Jeffery, 2012, Fig. 4), and our specimen is presumably broken at the base of the enamel covering, so the extent of the non-enamelled crown and root cannot be determined with precision. Furthermore, the needle-toothed crocodilians, such as teleosaurids and metriorhynchids, generally displayed broader, shorter teeth. Only certain species of Steneosaurus and Teleosaurus had such truly needle-like teeth, and yet these teeth were curved in two directions (Distally and labially) and these taxa are restricted stratigraphically to the Middle Jurassic (Buffetaut and Jeffery, 2012).

Among pterosaurs, those that contemplated this kind of teeth tended to have elongated and slightly curved teeth, but the length to maximum breadth ratio of the crown in Triassic and Jurassic forms is generally 0.12-0.50 (Wellnhofer, 1978). Pterosaurs underwent dramatic diversification in morphology in the Cretaceous (Prentice et al., 2011), and that includes their teeth - some clades, notably pteranodontids, lost their teeth entirely, whereas others (pterodactylids, germanodactylids, dsungaripterids, ornithodesmids) reduced the dentition to small numbers of short teeth. Only pterodaustrids and ctenochasmatids adopted long, slender teeth, and those of the former clade are hair-like or baleen-like (Wellnhofer, 1978; Martill, 2011). This suggests that the new teeth can be identified as ctenochasmatid, and in particular as gnathosaurine ctenochasmatid, an identification followed in analogous cases for long, slender, needle-like teeth in Early Cretaceous continental sedimentary deposits (e.g. Sánchez-Hernández et al., 2007, Fig. 5; Sweetman and Martill, 2010, Fig. 5). Ctenochasmatoid pterosaurs are well known mainly from the Early Cretaceous period in Asia, with numerous taxa from the Yixian Formation (early Aptian) of NE China (Lü et al., 2011), but with additional reports from South America (Martill, 2011) and Europe. Previous European reports include specimens from the Late Jurassic Solnhofen Limestone Formation (Tithonian) of southern Germany and equivalent-aged rocks of northern France (Bennett, 2007), the Purbeck Limestone Group (Berriasian) of southern England (Howse and Milner, 1995), and the Camarillas Formation (lower Barremian) of Burgos, Spain (Sánchez-Hernández et al., 2007) and the Leza Formation (Lower Cretaceous) of La Rioja, Spain (Pereda Suberbiola et al., 2012b).

The sauropod vertebra (CPGP. 1.06.33) shows the characteristics described in other caudal vertebrae of sauropods. As in the vertebrae described by Mantel on Pelorosaurus, it presents a Subcylindrical form and slightly concave facet (Mantel, 1850); and, as in the caudal vertebrae of Lusotitan described by Mannion et al. (2013), it has the posterior face of the centrum predominantly flat (Fig. 6.1) and it has a horizontal ridge 
on the lateral surface of the centrum (Fig 6.2) that divides it into an upper and lower regions (Mannion et al., 2013).

The assignment of a tooth (CPGP.1.06.2) to the genus $\mathrm{Ba}$ ryonyx is consistent with biometric studies of other teeth of this genus (Smith et al., 2005). This confirms the presence of Baryonyx in the Cabo Espichel, as reported earlier by Buffetaut (2007) and Mateus et al. (2011), one of them quite close to Praia das Aguncheiras (Mateus et al., 2011) is in concordance with our findings. The presence of a groove in the mesial carina can be explained by the way theropods gnawed the flesh and bones of prey, after applying the bite, dragging the teeth through the flesh and bones, which produced long grooves (Erickson and Olson, 1996).

During the Early Cretaceous the ornithopod faunas suffered some changes: the camptosaurids were gradually replaced by more derived iguanodontians and the smaller forms maintaining close species of Hypsilophodon, among others (Ortega et al., 2006, p. 226). Specimen CPGP.1.99.7 was initially assigned to an indeterminate Hypsilophodon (Figueiredo, 2002, 2004, 2005), and after to cf. Camptosaurus (Mateus, 2007; Figueiredo, 2008). However, after a more carefully comparative study, it appears that this fossil does not belong to this genus. The teeth are totally different from those of Hypsilophodon, and are bigger and wider (cheek teeth) than those of Camptosaurus. On the other hand, despite the wide geographic distribution of iguanodonts in the Early Cretaceous (Europe, North America, Asia, Africa and Australia) (Norman and Weishampel, 2004; Paul, 2007, 2012; Norman, 2011a, 2013; Carpenterand Ishida, 2010), the presence of Camptosaurus in the Barremian of Europe seems unlikely (Carpenter and Ishida, 2010; Paul, 2008). The teeth and maxilla bone have several similarities with the iguanodonts. The maxilla's labial surface is curved, like that of the iguanodonts and not flat, like Camptosaurus. As previously mentioned, it holds only one replacement tooth per tooth position, the labial surface of the crown is thickly enameled and has a strongly denticulated margin with a very large primary ridge arising from the base of the crown, on the lingual surface, the teeth do not display any ornamentation.

Pterosaurs frequented coastal and estuarine areas, Baryonyx fed primarily on fishes and small animals in habitats near the coast, the crocodile Goniopholis also lived in coastal environments, and the fish Lepidotes are characteristic of lagoon habitats. These observations are in concordance with the sedimentological analysis.

\subsection{Comparison of fauna}

The fauna of the Papo-Seco Formation of SW Portugal, consisting of fishes (Lepidotes), crocodilians (cf. Anteophthaosuchus), pterosaurs (ctenochasmatoid and a possible ornithocheirid) and dinosaurs (Baryonyx, sauropods, iguanodonts) is very comparable with those of similar age (early Barremian) from England (e.g. Vectis Formation, Upper Weald Clay) and from Spain, in Galve, Uña, Burgos, Gol- mayo and Las Hoyas, (e.g. Estes and Sanchez, 1982; Sanz et al., 1984; Sanz et al., 1987; Buscalioni and Sanz, 1987; Ruiz-Omeñaca et al., 2004; Fuentes Vidarte et al., 2005; Ortega et al., 2006 Sánchez-Hernández et al., 2007, Sweetman and Martill, 2010; Serrano et al., 2013; Buscalioni et al., 2013; Puértolas-Pascual et al., 2015). Lepidotes and Goniopholidids are ubiquitous throughout the world in the Early Cretaceous. Goniopholidids are one of the most common taxa of the crocodylomorph European Mesozoic fossil record (Buscalioni et al., 2013) and teeth and osteoderms are dominant remains in fossil assemblages (Schwarz, 2002; Salisbury and Naish, 2011). G. baryglyphaeus occurred in the Iberian Peninsula, in the Upper Jurassic (Kimmeridgian) of Portugal in the Alcobaça Formation (Brinkmann, 1989; Crespo, 2002; Schwarz, 2002; Malafaia et al., 2006). In different formations of Spain of chronologies between the Berriasian and the Aptian several taxa of goniopholidids were identified (Buscalioni and Sanz, 1987; Buscalioni et al., 2013). The European goniopholidids are composed of three genera (Goniopholis, Hulkepholi and Anteophthamosuchus) and there is also another goniopholidd, the "Dollo specimen". The genus Goniopholis has a biochronological distribution between the Kimmeridgian and the Berriasian. The others goniopholidids are known from the Valengianian to the Aptian (Andrade et al., 2011). The Papo-Seco Formation dates from the Barremian, therefore within the period of occurrence of the genera Hulkepholi and Anteophthamosuchus. The materials from Areias do Mastro are the first occurrences of goniopholids from the Lower Cretaceous fossil record in Portugal. Among pterosaurs, ornithocheirids have long been known from the Early Cretaceous of Europe, whereas ctenochasmatoids were formerly seen as mainly Asiatic in distribution. Now, however, both clades are reported from southern England and from the Galve fauna of Spain (Sánchez-Hernández et al., 2007).

Among the dinosaurs, baryonychid theropods, pelorosaurid sauropods, the occurrence of three teeth of sauropod (Astrodon valdensis) at the Papo-Seco Formation (Lapparent and Zbyszewski, 1957; Dantas, 1990; Antunes and Mateus, 2003; Figueiredo, 2005, 2010; Mateus et al., 2011) should be noted, and iguanodontians are typical Early Cretaceous forms, known throughout Europe (Weishampel et al., 2004; Sánchez-Hernández et al., 2007; Norman, 2011a). With larger collections, other dinosaur groups expected from this site might be spinosaurid theropods, hypsilophodontid-like ornithopods, and armour plates of stegosaurs or ankylosaurs. The iguanodonts appear in several formations of Lower Cretaceous of Western Europe, such as Sainte-Barbarbe Clays, Vectis Fm., Camarrilas Fm. Pinila de los Moros Fm. Castrillo de la Reina Fm. and Wessex Fm. In these formations there are referred the genera Iguanodon, Mantellisaurus, Delapparentia and Proplanicoxa (junior synonym of Mantellisaurus by Norman, 2011b) (Sanz et al., 1984, 1987; Buscalioni and Sanz, 1987; Ortega et al., 2006, Torcida Fernández-Baldor, 2006; Paul, 2008, 2012; Carpenter and Ishida, 2010; Llandres Serrano et al., 2013, Gasca et al., 2014). The remains of 
iguanodonts presented in this study display a better fit with the first two (Iguanodon and Mantellisaurus).

\section{Conclusions}

The palaeontological site of Areias do Mastro has yielded an important set of remains, including fossils of vertebrates. These include several fossils of fishes and reptiles (crocodiles, pterosaurs and dinosaurs). The presence of some taxa in the site is recognized here for the first time, including the three teeth of pterosaurs (two teeth of Ctenochasmatoidea, and a tooth of Ornithocheiridae), are the only taxon known in the Early Cretaceous of Portugal, excluding a vertebra referred by Galton (1994).

In addition, dinosaur remains (sauropod, iguanodonts and Baryonyx) which may have derived from several inland environments, likely transported to the present location where the sediments indicate marine and continental environments.

Most of the remains were collected in a single stratum, which gives us an idea of the fossiliferous association, consisting of crocodiles and turtle remains identified in other studies (Figueiredo, 2002, 2004, 2005), dinosaurs, pterosaurs, and fishes. The sediments of the studied layer indicate a continental shelf deposition zone, in calm lagoon waters frequented by marine fauna, and mixed with transported remains of land animals that lived nearby and on the shores of this lagoon. The faunal remains confirm the sedimentological analysis, mainly because pterosaurs (Baryonyx and Goniopholidids) frequented coastal and estuarine areas and fish Lepidotes are characteristic of lagoonal habitats.

The reference to Cretaceous dinosaurs ornithischians in Portuguese territory is rare (Figueiredo, 2014). The Iguanodon referenced by Lapparent and Zbyszewiski, 1957 is among the few specimens referenced. The identification of the three remains of Iguanodonts increases the registration and diversity of these dinosaurs from the Portuguese Lower Cretaceous.

\section{Acknowledgements}

We would like to thank Michael Benton for the classification and description of the pterosaurs' teeth and for his revision and suggestions on the original text, to Américo Rosa and Fernando Coimbra for helping with the translation from the original Portuguese version to the English version, to Luís Santos for the final revision of the English, to Sérgio Nunes for helping with the biometric study, all the team members who have collaborated in the fieldwork, and especially Sandro Figueiredo for his paleontological discoveries, Arlinda Fortes for her support in the improve of the images, Sandra Subtil (Petset) and Natalina Pimenta and Bruno Ferreira (Hospital de Seia), for the maxilla X-ray CPGP.1.99.7. Finally, to Ciência Viva - Agencia Nacional para a Cultura Científica e Tecnológica, which has financially supported the field work since 2002 through the program "Ocupação Científica dos Jovens nas Férias" (Scientific Occupation of Youngsters During Holidays), involving young people of the secondary school level.

\section{References}

Agassiz L.R. (1832): Untersuchungen über die fossilen Fische der LiasFormation. Neues Jahrbuch für Mineralogie, Geognosie. Geologie und Petrefaktenkunde 3,139-149.

Alonso, A., Canudo, J.I. (2015): On the spnosaurid theropod teeth from the early Barremian (Early Cretaceous) Blesa Formation (Spain). Historical Biology 1-12. DOI: 10.1080/08912963.2015.1036751.

Alonso, A., Canudo, J.I., Navarro-Lorbés, P., Cuenca-Bescós, G. (2015): Morfolometría geométrica aplicada al estudio de dientes aislados de dinosaurios terópodos. XIII EJIP Conference Proceedings, pp. 19-21.

Andrade, M.B., Edmonds, R., Benton, M.J., Schouten, R. (2011): A new Berriasian species of Goniopholis (Mesoeucrocodylia, Neosuchia) from England, and a review of the genus. Zoological Journal of the Linnean Society 163, 66-108.

Antunes, M.T., Mateus, O. (2003): Dinosaurs of Portugal. Comptes Rendus Palevol 2, 77-95.

Arambourg, C., L. Bertin. (1958): Super-Ordres des Holostéens et des Halécostomes (Holostei et Halecostomi), p. 2173-2203. In: P. Grassé (ed.), Traité de Zoologie 13(3). Masson et Cie, Paris.

Averianov, A.O. (2007) : Mid-Cretaceous Ornithocheirids (Pterosauria, Ornithocheiridae) from Russia and Uzbekistan. Paleontological Journal 41, 79-86.

Barrett, P.M., Willis, K.J. (2001): Did dinosaur invent flowers? Dinosaur-angiosperm coevolution revisited. Biological Reviews 76, 411447.

Batten, D.J. (2011): English Wealden fossils. Field guides to fossils 14. John Wiley \& Sons, London, 769 pp.

Bennett, S.C. (2007): A review of the pterosaur Ctenochasma: taxonomy and ontogeny. Neues Jahrbuch für Geologie und Paläontologie, Abhandlungen 245, 23-31. doi: 10.1127/0077-7749/2007/0245-0023.

Benton, M.J., Clark, J.M. (1988): Archosaur phylogeny and the relationships of the Crocodylia. In: M.J. Benton (ed.), The Phylogeny and Classification of the Tetrapods. Vol. 1, 295-338. Clarendon Press, Oxford.

Benton, M. J., Spencer, P.S. (1995): Fossil reptiles of Great Britain. Chapman \& Hall, London, 386 pp.

Brinkmann, W. (1989): Vorläufige Mitteilung über die KrokodilierFaunen aus dem Ober-Jura (Kimmeridgium) der Kohlegrube Guimarota, bei Leiria (Portugal) und der Unter-Kreide (Barremium) von Uña (Provinz Cuenca, Spanien). Documenta naturae 56, 1-28.

Buffetaut, E. (2007): The spinosaurid dinosaur Baryonyx (Saurischia, Theropoda) in the Early Cretaceous of Portugal. Geological Magazine 144, 1021-1025.

Buffetaut, E., Jeffrey, P. (2012): A ctenochasmatid pterosaur from the Stonesfield Slate (Bathonian, Middle Jurassic) of Oxfordshire, England. Geological Magazine 149, 552-556.

Buscalioni, A. D., Sanz, J. L., (1987): Lista Faunística de los Vertebrados de Galve (Teruel), Estudios geológicos, Vol. extr, Galve-Tremp, 65-67.

Buscalioni, A.D., Alcalá, L., Espílez, E., Mampel, L. (2013): European Goniopholididae from the Early Albian Escucha Formation in Ariño (Teruel, Aragón, España). Spanish Journal of Paleontology 28, 103-122.

Carpenter, K., Ishida, Y. (2010): Early and "Middle" Cretaceous iguanodonts in time and space. Journal of Iberian Geology 36 (2), 145-164.

Charig A.J., Milner, A.C. (1986): Baryonyx, a remarkable new theropod dinosaur. Nature 324, 359-361.

Choffat, P. (1904-1907): Le Crétacique dans l'Árrabida et dans la 
contrée d'Ericeira. Comunicações da Comissão do Serviço Geológicao de Portugal 6, 1-51.

Cope, E.D. (1875): Check-list of North American Batrachia and Reptilia with a systematic list of the higher groups and an essay on geographical distribution based on the specimens in the U.S. National Museum. Bulletin of the United States National Museum 1, 1-104.

Cope, E.D. (1871): Contribution to the ichthyology of the Lesser Antilles. Transactions of the American Philosophical Society 14, 445-483.

Cope, E.D. (1872): Observations on the systematic relations of the fishes. Proceedings of the American Association for the Advancement of Science 20, 317-343.

Crespo, E. G. (2001): Paleo-Herpetofauna de Portugal. Museu BocageM.N.H.N., Lisboa, 183 p.

Crespo, E.G. (2002): Paleoherpetofauna Portuguesa. Revista Española de Herpetología 17-35.

Dantas, P. (1990): Dinossáurios de Portugal. Gaia 2, 17-26.

Dinis, J.L., Rey, J., Callapez, P., Cunha, P.P., Pena dos Reis, R. (2008): Stratigraphy and allogenic controls of the western Portugal Cretaceous: an updated synthesis. Cretaceous Research 29, 772-780.

Dollo, L. (1888): Iguanodontidae et Camptonotidae. Comptes Rendus de l'Académie des Sciences Paris 106, 775-777.

Erickson, G.M., Olson, K. H. (1996): Bite marks attribute to Tyrannosaurus rex: preliminary description and implications. Journal of Vertebrate Paleontology 16, 175-178.

Estes, R.., Sanchíz, B. (1982): Early Cretaceous lower vertebrates from Galve (Teruel), Spain. Journal of Vertebrate Palaeontology 2, 21-39.

Ferreira, O.V. (1961): Fauna ictyologica do Cretácico de Portugal. Comunicações da Comissão dos Serviços Geológicaos de Portugal 45 , 249-278.

Figueiredo, S. (2000): Classificação do dente $n^{0} 10$ do Museu Geológico. Boletim do Centro Português de Geo-História e Pré-História, I Série, $1,3$.

Figueiredo, S. (2002): Os dinossauros da Arrábida. Revista Evolução1, $5-8$.

Figueiredo, S. (2004): Os dinossauros do Cabo Espichel. Techne 9, 285 -290 .

Figueiredo, S. (2005): Os dinossauros do Cabo Espichel. Paleontologia e Arqueologia do Estuário do Tejo, Actas do I Seminário; Colecção estudos locais e cultura; Edições Colibri, C. M. Montijo, 81-90.

Figueiredo, S. (2007): Sobre o Estudo Preliminar de um Fragmento de Ulna de Pequeno Terópode de Areias de Mastro - Sesimbra. Boletim do Centro Português de Geo-História e Pré-História, III, Série, 2, pp. 21-28.

Figueiredo, S. (2008): Dinossauros de Portugal. Edições Cosmos, Chamusca, $152 \mathrm{p}$.

Figueiredo, S. (2010): Breve Notícia sobre a Descoberta de um Novo Dinossáurio Ornitópode no Cabo Espichel. Boletim do Centro Português de Geo-História e Pré-História, III Série, 3, pp. 7-15.

Figueiredo, S. (2014): Os Dinossáurios em Território Português: as espécies, as jazidas e os fósseis. Chiado Editora, Lisboa, 232 p.

Fowler, DW. (2007): Recently Rediscovered Baryonychine Teeth (Dinosauria: Theropoda): New Morphologic Data, Range Extension and Similarity to Ceratosaurus. Journal of Vertebrate Paleontology 27 (sup. 3). 76A.

Fuentes Vidarte, C., Meijide Calvo, M., Meijide Fuentes, F., Meijide Fuentes, M. (2005): Fauna de vertebrados del Cretácico Inferior del Yacimiento de "Zorralbo" en Golmayo (Soria, España). [Vertebrate fauna (Lower Cretaceous) of the site "Zorralbo" a Golmayo (Soria, Spain).] Revista Española de Paleontología, N.E.X, 83-92.

Galton, P.M. (1994): Notes on Dinosauria and Pterodactylia from the Cretaceous of Portugal. Neues Jahrbuch für Geologie und Paläontologie, Abhandlungen 194, 253-267.

Gasca, J.M., Canudo, J.I., Moreno-Azanza, M. (2009): New iguanodontian dinosaur remains from the Early Barremian of Spain (Castellote,
Teruel). Journal of Vertebrate Paleontology 29 (supplement to 3), p. $103 \mathrm{~A}$.

Gasca, J.M., Canudo, J.I., Moreno-Azanza, M. (2014): On the diversity of Iberian iguanodont dinosaurs: New fossils from the lower Barremian, Teruel province, Spain. Cretaceous Research 50, 264-272. doi: 10.1016/j.cretres.2014.05.009

Gasca, J.M., Moreno-Azanza, J. M., Ruiz-Omeñaca, J. I., Canudo, J. I. (2015): New material and phylogenetic position of the basal iguanodont dinosaur Delapparentia turolensis from the Barremian (Early Cretaceous) of Spain. Journal of Iberian Geology 41 (1), 57-70

Hay, O.P. (1930): Second Bibliography and Catalogue of the Fossil Vertebrates of North America. Vol. 2. Publications of the Carnegie Institute, Washington, DC, pp. 1-390.

Howse, S., Milner, A.R. (1995): The pterodactyloids from the Purbeck Limestone Formation of Dorset. Bulletin of the Natural History Museum, London (Geology) 51, 73-88.

Huxley, T. H. (1880): On the application of the laws of evolution to the arrangement of the Vertebrata, and more particularly of the Mammalia. Proceedings of the Zoological Society, London 43, 649-662

Lapparent, A.F. de, Zbyszewski, G. (1957): Les dinosauriens du Portugal. Memorias de Serviços Geológicos de Portugal, Lisboa (N.S.) 2, 1-63.

Llandres Serrano, M., Marugán-Lobón, R. V. J., Ortega, F., Buscalioni, A. (2013): An articulated hindlimb of a basal iguanodont (Dinosauria, Ornithopoda) from the Early Cretaceous Las Hoyas Lagerstätte (Spain) Geol. Mag. 150, 572-576. doi:10.1017/S0016756813000095

Lloyd, G.T., Davis, K.E., Pisani, D., Tarver, J.E., Ruta, M., Sakamoto, M., Hone, D.W.E., Jennings, R., Benton, M.J. (2008): Dinosaurs and the Cretaceous Terrestrial Revolution. Proceedings of the Royal Society of London. Biological Sciences 275, 2483-2490.

Lü, J., Ji, Q., Wei, X.-f., Liu, Y.-q. (2011): A new ctenochasmatoid pterosaur from the Early Cretaceous Yixian Formation of western Liaoning, China. Cretaceous Research 34, 26-30.

Malafaia, E., Ortega, F., Escaso, F., Dantas, P., Pimentel, N., Gasulla, J. M., Ribeiro, B., Barriga F., Sanz, J.L. (2010): Vertebrate fauna at the Allosaurus (Upper Jurassic), Pombal, Portugal. Journal of Iberian Geology 36 (2) 193-204 doi:10.5209/rev_JIGE.2010.v36.n2.7

Mantell, G.A. (1850): On the Pelorosaurus: an undescribed gigantic terrestrial reptile, whose remains are associated with those of the Iguanodon and other saurians in the strata of Tilgate Forest, in Sussex. Philosophical Transactions of the Royal Society of London 140, 379-390.

Manupella, G., Antunes, M.T., Pais, J., Ramalho, M.M., Rey, J. (1999): Notícia explicativa da Carta Geológica de Setúbal. Serviços Geológicos de Portugal, Lisboa, $143 \mathrm{p}$.

Marsh O. C. (1878): Principal characters of American Jurassic dinosaurs. Part I. American Journal of Science 16, 411-416.

Martill, D.M. (2011): A new pterodactyloid pterosaur from the Santana Formation (Cretaceous) of Brazil. Cretaceous Research 32, 236-243.

Massare, J.A. (1987): Tooth morphology and prey preference of Mesozoic marine reptiles. Paleobiology 7, 121-137.

Mateus, O. (2007): Notes and review of the ornithischian dinosaurs of Portugal. Journal of Vertebrate Palaeontology 27 (suppl. T. 3), 114A.

Mateus, O., Araújo, R., Natário, C., Castanhinha, R. (2011): A new specimen of the theropod dinosaur Baryonyx from the early Cretaceous of Portugal and taxonomic validity of Suchosaurus. Zootaxa 2827, 54-68.

Norman, D.B., Weishampel, D.B. (2004): Basal Ornithopoda, in The Dinosauria (2 ${ }^{\text {nd }}$ ed.). Weishampel, D.B., Dodson, P., Osmólska (eds), University of California Press, 395-412, California.

Norman, D. B. (2010): A taxonomy of iguanodontians (Dinosauria: Ornithopoda) from the lower Wealden Group (Cretaceous: Valanginian) of southern England. Zootaxa 2489, 47-66

Norman, D. (2011a): The ornithopod dinosaurs. In: Batten, D. (ed.), 
English Wealden fossils. The Paleontological Association, London, pp. 407-475.

Norman, D.B. (2011b): On the osteology of the lower wealden (Valanginian) ornithopod Barilium dawsoni (Iguanodontia: Styracosterna). Special Papers in Palaeontology 86, 165-194

Norman, D. B. (2013): On the taxonomy and diversity of Wealden iguanodontian dinosaurs (Ornithischia: Ornithopoda). Revue de Paléobiologie 32 (2), 385-404.

Ortega, F., Escaso, F., Gasulla, J. M., Dantas, P., Sanz, J. L. (2006): Dinosaurios de la Península Ibérica. Estudios Geológicos 62 (1), 219 240.

Paul, G.S. (2008): A Revised taxonomy of the iguanodont dinosaur genera and species. Cretaceous Research 29, 192-216

Paul, G. S. (2012): Notes on the rising diversity of Iguanodont taxa, and Iguanodonts named after Darwin, Huxley, and evolutionary science. Actas de V Jornadas Internacionales sobre Paleontología de Dinosaurios y su Entorno, Salas de los Infantes, Burgos. 123-133.

Pereda-Suberbiola, X., Ruiz-Omeñaca, J.I., Torcida Fernández-Baldor, F., Maisch, M.W., Huerta, P., Contreras, R., Izquierdo, L.A., Montero Huerta, D., Urién Montero, V., Welle, J. (2011): A tall-spined ornithopod dinosaur from the Early Cretaceous of Salas de los Infantes (Burgos, Spain). Comptes Rendus Palevol 10, 551-558. doi: 10.1016/j. crpv.2011.04.003

Pereda-Suberbiola, X., Ruiz-Omeñaca, J.I., Canudo, J.I., Torcida, F., Sanz, J.L. (2012a): Dinosaur faunas from the Early Cretaceous (Valanginian-Albian) of Spain. In: P. Godefroit (ed.), Bernissart dinosaurs and early Cretaceous terrestrial ecosystem. Indiana University Press, Bloomington, pp. 379-407.

Pereda-Suberbiola, X., Knoll, F., Ruiz-Omeñaca, J.I., Company, J., Torcida Fernández-Baldor, F. (2012b): Reassessment of Prejanopterus curvirostris, a Basal Pterodactyloid Pterosaur from the Early Cretaceous of Spain. Acta Geologica Sinica 86 (6), 1389-1401. doi:10.1111/1755-6724.12008.

Plieninger, F. (1901): Beiträge zur kenntnis der flugsaurier. Paläontographica 48, 65-90.

Prentice, K.C., Ruta, M., Benton, M.J. (2011): Evolution of morphological disparity in pterosaurs. Journal of Systematic Palaeontology 9, 337-353. doi: 10.1080/14772019.2011.565081.

Puértolas-Pascual, E., Canudo, J.I., Sender, L.M. (2015): New material from a huge specimen of Anteophthalmosuchus cf. escuchae (Goniopholididae) from the Albian of Andorra (Teruel, Spain): Phylogenetic implications. Journal of Iberian Geology 41 (1) 2015, 41-56

Rey, J. (1972): Recherches géologiques sur le Crétacé inférieur de l'Estremdura (Portugal). Memórias dos Serviços Geológicaos de Portugal 21, 1-477.

Ruiz-Omeñaca, J.I., Canudo, J. L., Aurell, M., Bádenas, B., Barco, J. L., Cuenca-Bescós, Ipas, J.G. (2004): Estado de las Investigaciones sobre los Vertebrados del Jurassico Superior y Cretacico Inferior de Galve (Teruel). Estudios Geologicos 60, 179-202.

Ruiz-Omeñaca, J.I. (2011): Delapparentia turolensis nov. gen. et sp., un nuevo iguanodontoideo (Ornithischia: Ornithopoda) en el Cretácico Inferior de Galve. Estudios geológicos 67, 83-110. doi: 10.3989/ egeol.40276.124

Salisbury, S.W., Naish, D. (2011): Crocodilians. In: D.J. Batten (ed.), English Wealden Fossils. The Palaeontological Association, London, pp. 305-369.
Sánchez-Hernández, B., Benton, M.J., Naish, D. (2007): Dinosaurs and other fossil vertebrates from the Late Jurassic and Early Cretaceous of the Galve area, NE Spain. Palaeogeography, Palaeoclimatology, Palaeoecology 249, 180-215.

Sanz, J. L., Casanovas, M. L., Santafé, J. V. (1984): Restos autopodiales de Iguanodon (Reptilia, Ornithopoda) del yacimiento de Santa Bárbara (Cretácico inferior,

Galve, Provincia de Teruel, España). Estudios Geológicos 40, 251-257.

Sanz, J. L., Buscalioni, A. D., Casanovas, M. L., Santafé, J. V. (1987): Dinosaurios del Cretácico inferior de Galve (Teruel, España). Estudios Geol., vol. Extr. Galve-Tremp, 45-64.

Sauvage, H. E. (1897-8): Vertébrés fossiles du Portugal. Direction des Travaux Géologiques du Portugal 1897-1898, 1-46.

Schwarz, D. (2002): A new species of Goniopholis from the Upper Jurassic of Portugal. Palaeontology 45, 185-208. doi: 10.1111/14754983.00233

Seeley, H. G. (1870): The Ornithosauria: an elementary study of the bones of pterodactyls, made from fossil remains found in the Cambridge Upper Greensand, and arranged in the Woodwardian Museum of the University of Cambridge. Deighton, Bell and Company, Cambridge. $x i i+135 \mathrm{p}$.

Sereno, P.C. (1986): Phylogeny of the bird-hipped dinosaurs (Order Ornithischia). National Geographic Research 2, 234-256.

Smith, J.B., Vann, D.R., Dodson, P. (2005): Dental morphology and variation in theropod dinosaurs: implications for the taxonomic identification of isolated teeth. The Anatomical Record 285A, 699-736.

Stromer E. (1915): Ergebnisse der Forschungsreisen Prof. E. Stromers in den Wüsten A gyptens: II, Wirbeltier-Reste der Baharije-Stufe (unterstes Cenoman) - 3, das Original des Theropoden Spinosaurus aegyptiacus nov. gen., nov. spec. Abhandlungen der Königlich Bayerischen Akademie der Wissenschaften Mathematischphysikalische Classe Abhandlung Neue Folge 28,1-32.

Sweetman, S.C., Martill, D.M. (2010): Pterosaurs of the Wessex Formation (Early Cretaceous, Barremian) of the Isle of Wight, southern England: a review with new data. Journal of Iberian Geology 36, $225-$ 242. doi: 10.5209/rev_JIGE.2010.v36.n2.9.

Taylor, M.P. (2010): Sauropod dinosaur research: a historical review. In: Moody, R.T.J., Buffetaut, E., Naish, D., Martill, D.M. (eds), Dinosaurs and other extinct saurians: a historical perspective. Special Publication of the Geological Society 343, 361-386.

Torcida Fernández-Baldor, F. 2006: Restos directos de dinosaurios en Burgos (Sistema Ibérico): un balance provisional. Actas de las III Jornadas Internacionales sobre Paleontología de Dinosaurios y su Entorno. Ed. Colectivo Arqueológico y Paleontológico de Salas. Salas de los Infantes 105-128.

Vermeij, G.J., Grosberg, R.K., (2011): The great divergence: when did diversity on land exceed that in the sea? Integrative and Comparative Biology 50, 675-682.

Unwin, D. M. (1995): Preliminary results of a phylogenetic analysis of the Pterosauria (Diapsida: Archosauria). Sixth Symposium on Mesozoic terrestrial Ecosystems and Biota. Short Papers, China Ocean Press, Beijing, 69-72.

Weishampel, D.B., Dodson, P., Osmólska, H. (2004): The Dinosauria. Berkeley, University of California Press.

Wellnhofer, P. (1978): Pterosauria. Handbuch der Paläoherpetologie 19, 1-82. Gustav Fischer, Stuttgart. 